A RCHIWA, BIBLIOTEKI

I MUZEA KOŚCIELNE 110 (2018)

https://doi.org/10.31743/abmk.2018.110.24

ŁUKASZ WŁODARSKI* - TORUŃ

\title{
URZĘDNICY DWORSCY BISKUPA PLOCKIEGO ANDRZEJA HERBU CIOLEK (1254-1261). PRZYCZYNEK DO BADAŃ NAD DWORAMI BISKUPIMI W ŚREDNIOWIECZNEJ POLSCE**
}

W polskiej historiografii badania nad dworami koncentrowały się dotychczas przede wszystkim na otoczeniu królewskim ${ }^{1}$ oraz książęcym ${ }^{2}$. Stosunkowo nieliczne wydają się być studia nad poświęcone dworom hierarchów kościelnych ${ }^{3}$.

* Łukasz Włodarski - mgr historii; doktorant w Instytucie Historii i Archiwistyki; Uniwersytet Mikołaja Kopernika w Toruniu; e-mail: wlodarski24@gmail.com

ORCID 0000-0001-8615-1835

** Praca naukowa finansowana ze środków budżetowych na naukę w latach 2014-2018, jako projekt badawczy w ramach programu Diamentowy Grant.

${ }^{1}$ Zob. np. H. Kręt, Dwór królewski Jadwigi i Jagietty, Kraków 1987; G. Rutkowska, Itineraria żon króla Władystawa Jagietly, „Roczniki Historyczne”, 64 (1998), s. 59-104; taż, Urzędnicy królowej Jadwigi Andegaweńskiej. Spis, w: Nihil superfluum esse. Prace z dziejów średniowiecza ofiarowane Profesor Jadwidze Krzyżaniakowej, red. J. Strzelczyk, J. Dobosz, przy współpracy Z. Górczaka, Poznań 2000, s. 367-391; B. Czwojdrak, Z badań nad dworem królowej Zofii Holszańskiej, „Średniowiecze Polski i Powszechne”, 2 (6) (2010), s. 157-178; taż, Zofia Holszańska. Studium o dworze i roli królowej w późnośredniowiecznej Polsce, Warszawa 2012; taż, Dwory królewskie $w$ Polsce $w X V$ wieku - stan badań i postulaty badawcze, w: Curia regis, curia reginalis. Dwory królewskie w średniowiecznej Europie Środkowej - stan badań i postulaty badawcze, red. B. Czwojdrak, A. Januszek-Sieradzka, Sandomierz 2014, s. 59-71 (tu również pełne zestawienie starszej literatury); G. Rutkowska, Dwór królewski w Polsce w XIV wieku - stan badań i postulaty badawcze, w: Curia regis, s. 45-57 (tu również pełne zestawienie starszej literatury); B. Czwojdrak, Fraucymer na dworach królowych w późnośredniowiecznej Polsce, „Studia z Dziejów Średniowiecza", 20 (2016) s. 17-28; taż, Liczebność dworów późnośredniowiecznych i wczesnonowożytnych władców polskich, „Roczniki Dziejów Społecznych i Gospodarczych”, 76 (2016) s. $209-220$.

${ }^{2}$ Zob. np. A. Supruniuk, Otoczenie księcia mazowieckiego Siemowita IV (1374-1426). Studium o elicie politycznej Mazowsza na przełomie XIV i XV wieku, Warszawa 1998; J. Sperka, Otoczenie Władysława Opolczyka w latach 1370-1401. Studium o elicie władzy w relacjach z monarcha, Katowice 2006.

${ }^{3}$ Zob. np. M. Friedberg, Klientela świecka biskupa krakowskiego w wieku XII-XIV, Kraków 1938; S. Hain, Wincenty Kot prymas Polski 1436-1448, Poznań 1948; A. Tomczak, Kancelaria 
Ze względu na słabe, wynikające m.in. ze stanu zachowania bazy źródłowej, zainteresowanie historyków biografistyką średniowiecznego episkopatu płockiego, niezmiernie skąpe są dokonania naukowców odnoszące się do dworów biskupów płockich. Właściwie należy wspomnieć tylko trzy prace. Pierwsza to monografia autorstwa E. Suchodolskiej traktująca o kancelariach na Mazowszu (w tym również biskupów płockich) w latach 1248-13454. Kolejna, to artykuł poświęcony Pawłowi Giżyckiemu h. Gozdawa (1439-1463) i jego działalności kościelnej, politycznej i gospodarczej, gdzie poruszono kwestię otoczenia i kancelarii Gozdawity ${ }^{5}$. Zaś ostatnia z nich traktuje wyłącznie o kancelarii Klemensa h. Pierzchała (1333-1357) i jej wytworach ${ }^{6}$. W związku z powyższym zasadnym jest podjęcie dalszych, pogłębionych badań nad dworami oraz otoczeniem biskupów płockich doby średniowiecza. Na łamach niniejszego przyczynku przedstawimy urzędników dworskich Andrzeja Ciołka, ordynariusza płockiego w latach 1254-1261. Wybór tego dostojnika na przedmiot naszego zainteresowania związany jest również z faktem, że na dyplomach z okresu jego pontyfikatu po raz pierwszy w otoczeniu biskupów płockich pojawiają się osoby sprawujące urzędy stricte dworskie. Ze względu na charakter zachowanego materiału źródłowego zmuszeni jesteśmy do oparcia swoich badań wyłącznie na testacjach dokumentów wygotowanych zarówno przez kancelarię biskupią, jak i innych wystawców; zdając sobie jednocześnie sprawę z mankamentów, jakie niesie ze sobą stosowana metoda.

Z racji szczupłości źródeł niewiele da się powiedzieć o młodości Andrzeja. Wiadomo jedynie, że wywodził się z mazowieckiej linii Ciołków. W 1244 r., wraz ze swoim bratem Hipolitem, był współwłaścicielem wsi Wsetropie (obecnie Setropie koło Drobina). Równolegle do kariery duchownej (prepozyt katedry płockiej) pełnił służbę na dworach książąt mazowieckich - Bolesława I, Konrada oraz Siemowita I - gdzie sprawował urząd kanclerza, którym pozostawał zapewne do objęcia godności biskupiej. Co do wyboru na biskupa płockiego nie dysponujemy żadną dokładną datą. Nie znamy również daty śmierci jego poprzednika - Piotra zw. Brevis. Niemniej jego wybór musiał nastąpić przed 8 maja 1254 r., gdyż

biskupów włocławskich w okresie księgi wpisów (XV-XVIII w.), Toruń 1964; I. Skierska, Dwór i urząd biskupi w późnośredniowiecznej diecezji poznańskiej, „Roczniki Historyczne”, 60 (1994), s. 185-202; Z. Wilk-Woś, Władysław z Oporowa (ok. 1395-1453). Podkanclerzy królewski, biskup włocławski i arcybiskup gnieźnieński, „Studia Claramontana”, 21 (2003), s. 175-459; taż, Późnośredniowieczna kancelaria arcybiskupów gnieźnieńskich (1436-1493), Łódź 2013; M. Koczerska, Zbigniew Oleśnicki i Kościót krakowski w czasach jego pontyfikatu 1423-1455, Warszawa 2004; Ł. Włodarski, Dwór i najbliższe otoczenie arcybiskupa gnieźnieńskiego Jarosława Bogorii ze Skotnik (1342-1374), „Studia z Dziejów Średniowiecza”, 19 (2015) s. 225-256.

${ }^{4}$ E. Suchodolska, Kancelarie na Mazowszu w latach 1248-1345.Ośrodki zarządzania i kultury, Warszawa 1977 (zwłaszcza strony 40-52).

${ }^{5}$ P. Chojnacki, Biskup płocki Pawet Giżycki (1439-1463) i jego działalność, w: Z biografistyki Polski późnego średniowiecza (Fasciculi Historici Novi, t. 4), red. M. Koczerska, Warszawa 2001, s. 87-187.

${ }^{6}$ J. Grabowski, Dokumenty $i$ kancelaria biskupa plockiego Klemensa Pierzchaty $w$ latach (1333-1357), w: Państwo i Kościót w dziejach, źródtach i studiach nad przeszłościa, red. M. Stawski, Warszawa 2008, s.145-168. 
wówczas, już jako ordynariusz płocki, uczestniczył w uroczystościach kanonizacyjnych św. Stanisława, które odbyły się w Krakowie. Ciołek uchodził za dobrego zarządcę dóbr kościelnych - trakcie swojego pontyfikatu wyjednał chociażby od księcia Siemowita przywilej zasiedlania dóbr biskupich lokowanych na prawie niemieckim. Uzyskał również zobowiązanie księcia względem przestrzegania immunitetów nadanych Kościołowi płockiemu przez jego ojca i brata. Andrzej wspierał także materialnie działalność zakonu benedyktynów na terenie swojej diecezji. Zmarł 2 maja 1261 r. $^{7}$

Wydaje się, że pierwszą osobą, potwierdzoną źródłowo, którą możemy łączyć z otoczeniem Ciołka jest niejaki Mikołaj, prokurator biskupi (,praesentibus [...] Nicholaus procurator domini episcopi [sic!]"). Jego obecność rejestrujemy w testacji dyplomu książęcego Siemowita I dotyczącego potwierdzenia nadania wsi Słupia koło Bielska na rzecz katedry płockiej przez Żyrosława, syna komesa Klemensa $^{8}$. Datacja dokumentu (21 kwietnia 1254 r. w Płocku) pozwala nam przyjąć, chyba bez zbędnego ryzyka, że chodzi tu właśnie o biskupa Andrzeja. Jednocześnie lakoniczność przekazu nie pozwala nam doprecyzować, czym miałby się ów Mikołaj zajmować. Czy do jego obowiązków należało gospodarowanie dobrami mensy biskupiej w Płocku i okolicach, albo też w innym rejonie Mazowsza, czy może reprezentowanie ordynariusza $\mathrm{w}$ trakcie procesów sądowych (tu jednak regułą było imienne upoważnienie wystawiane dla danej osoby) - nie sposób dziś rozstrzygnąć.

$\mathrm{Z}$ całą pewnością dworzan Andrzeja Ciołka odnajdujemy 3 kwietnia $1256 \mathrm{r}$. w Mąkolinie (z. wyszogrodzka). W liście świadków dokumentu, z którego dowiadujemy się, że niejaki Michał syn Spicisza zobowiązał się zwrócić Andrzejowi 2/3 wsi Sobieski koło Płońska, przywłaszczoną niegdyś przez jego brata Gosława Spiciszowica, wystąpiło aż trzech kapelanów biskupich („Gostko, Paulus, Goslaus, capellani memorati domini episcopi Plocensis") ${ }^{9}$. Wymienieni zostali oni na końcu listy świadków, którymi oprócz nich byli: Piotr „,de Mislkouo" ${ }^{10}$, stolnik czerski Domasz, Bogumił dziedzic „de Osnichia”l1, a także „dominus Heynco” oraz „dominus Michael”. Należy zadać pytanie, jaki był status społeczny owych kapelanów oraz na czym polegały ich funkcje? Samo pojawienie się ich w Mąkolinie u boku ordynariusza stanowi silną przesłankę do zaliczenia ich w poczet biskupie-

${ }^{7}$ Por. J. Umiński, Andrzej h. Ciołek, biskup płocki, w: Polski Słownik Biograficzny, t. 1, Kraków 1935, s. 102; T. Żebrowski, Zarys dziejów diecezji płockiej, Płock 1976, s. 33-34; M.M. Grzybowski, L. Zyner, Episkopat płocki w latach 1075-2015. 940 lat istnienia diecezji, Płock 2015, s. 51-52.

${ }^{8}$ Nowy kodeks dyplomatyczny Mazowsza, cz. II, Dokumenty z lat 1248-1355 (dalej: NKDM), wyd. I. Sułkowska-Kuraś, S. Kuraś przy współudziale K. Pacuskiego i H. Wajsa, Wrocław 1989, nr 17.

${ }^{9} \mathrm{NKDM}, \mathrm{t} . \mathrm{II}, \mathrm{nr} 22$.

${ }^{10}$ Wedle wystawców źródła prawdopodobnie chodzi tu o wieś Mystkowo koło Płońska (własność szlachecka). Por. NKDM, t. II, nr 22, przyp. 3.

${ }^{11}$ Wedle wydawców źródła w grę wchodzi Ośnica koło Płocka (własność szlachecka) lub wieś o tej samej nazwie znajdująca się koło Makowa (własność szlachecka). Por. NKDM, t. II, nr 22, przyp. 5. 
go orszaku; jednak ze względu na szczupłość zachowanego materiału źródłowego nie jesteśmy w stanie ustalić nawet $\mathrm{w}$ przybliżeniu jego liczebności. W związku z tym, że stanowili oni klientelę duchowną Andrzeja możemy chyba wiązać ich $\mathrm{z}$ kancelarią biskupią ${ }^{12}$. Tezę tą może umacniać formuła korroboracyjna, z której dowiadujemy się o przywieszeniu do dokumentu pieczęci biskupiej (i świeckich świadków) ze względu na nie posiadanie takowej przez wystawcę ${ }^{13}$. Co za tym idzie w otoczeniu Ciołka musieli wówczas przebywać ludzie z jego kancelarii, którzy opiekowali się jego sigillum oraz zapewne spisali ten dokument ${ }^{14}$. Wszak to strona kościelna była najbardziej zainteresowana kwestią rewindykacji dóbr. Zresztą Andrzej sam wcześniej pełnił urząd kanclerski na dworach książąt mazowieckich, a co za tym idzie miał doświadczenie w tym, jak należy ją sprawnie zorganizować. Nie można również wykluczyć, że posługa owych kapelanów ograniczała się jedynie do obsługi kaplicy biskupiej oraz pełnienia funkcji spowiedników. Na kilka słów komentarza zasługują także przedstawiciele rycerstwa mazowieckiego, którzy zajęli trzy pierwsze miejsca w testacji. Ze względu na usytuowanie ich włości możemy przypuszczać, że prawdopodobnie należeli oni do osób znajdujących się w kręgu rodzinnym, bądź oddziaływania Michała Spiciszowica ${ }^{15}$.

Kolejnym dyplomem, na którym spotykamy osoby należące do otoczenia Andrzeja jest poświadczenie księcia Siemowita dotyczące darowania wsi Silnikowo koło Pułtuska na rzecz katedry płockiej przez wójta pułtuskiego Bogusza. Akt ten, z daty 11 lipca 1257 r., został wystawiony w stołecznym Płocku. W eschatokole tegoż dokumentu wspomniano o komorzym Piotrku oraz cześniku Mikołaju ${ }^{16}$. Prawdopodobnie do kompetencji pierwszego z nich należała piecza nad skarbem biskupim, a za całą pewnością odpowiadał on za nadzór nad sypialnią biskupią oraz personelem ją obsługującym (łożnych, pokojowców) ${ }^{17}$. Z kolei do zadań cześnika należało dbanie o piwnicę oraz nalewanie trunków na stole biskupim ${ }^{18}$. Warto zauważyć, że ich imiona zostały umieszczone na końcu testacji, zaraz po urzędnikach ziemskich, co również wiele mówi o ich ówczesnej pozycji społecznej.

Powyższe wzmianki odnoszące się do urzędników dworskich Andrzeja Ciołka dają nam wyraźną przesłankę, że jego otoczenie składało się z całą pewnością

${ }^{12}$ Analogiczne funkcje kapelanów w kancelariach kościelnych spotykamy, aczkolwiek późniejsze, na dworze biskupa krakowskiego Zbigniewa Oleśnickiego. Por. Koczerska, Zbigniew Oleśnicki, s. 66 .

${ }^{13} \mathrm{NKDM}$, nr 22 (,in cuius obligacionis firmum testimonium presentem cartulam tam predicti episcopi sigillo eo, quod meo careo, appensione quam virorum nobilium, qui hic mee obligacioni interfuerunt, subscricione duxi roborandam").

${ }^{14}$ Przeprowadzona przez E. Suchodolską (Kancelarie na Mazowszu, s. 50 ) analiza kodykologiczna nie rozstrzyga jednoznacznie kto mógł spisać ów dyplom. Niemniej autorka przypuszcza, iż mógł to być któryś z obecnych tam kapelanów.

${ }^{15}$ Por. przyp. 10 i 11.

${ }^{16}$ NKDM, nr 30 (,praesentibus [...] Piotrek camerarius episcopi Plocensis, Nicolaus pincerna eiusdem [sic!]").

${ }^{17}$ Por. A. Bogucki, Komornik i podkomorzy w Polsce Piastowskiej, w: Społeczeństwo Polski średniowiecznej, red. S.K. Kuczyński, t. III, Warszawa 1985, s. 123-132.

${ }^{18}$ Czwojdrak, Zofia Holszańska, s. 101; Włodarski , Dwór i najbliższe otoczenie, s. 230-231. 
z osób, które dbały o zaspokojenie jego potrzeb doczesnych, tj. przygotowanie posiłków oraz stołu do ich spożywania, komnaty do spania, zarządzanie dobrami (lub reprezentowanie biskupa przez osobę prokuratora), a także pracowników kancelarii, która umożliwiała sprawne zarządzanie diecezją (ewentualnie osób obsługujących kaplicę biskupią). Niestety stan zachowania źródeł dla XIII-wiecznego Mazowsza oraz warstwa informacyjna, którą one ze sobą niosą sprawiają, że niemożliwym staje się podjęcie szczegółowych badań prozopograficznych nad urzędnikami dworskimi Andrzeja. Domniemywać należy, że w skład dworu biskupiego wchodzili także skarbnicy, spowiednicy czy domownicy (familiares), którzy niestety pozostają nieuchwytni źródłowo.

\section{BIBLIOGRAFIA}

\section{Źródla}

Nowy kodeks dyplomatyczny Mazowsza, cz. II, Dokumenty z lat 1248-1355, wyd. I. Sułkowska-Kuraś, S. Kuraś przy współudziale K. Pacuskiego i H. Wajsa, Wrocław 1989.

\section{Opracowania}

Bogucki Ambroży, Komornik i podkomorzy w Polsce Piastowskiej, w: Społeczeństwo Polski średniowiecznej, red. S.K. Kuczyński, t. III, Warszawa 1985, s. 123-132.

Chojnacki Piotr, Biskup płocki Pawet Giżycki (1439-1463) i jego działalność, w: Z biografistyki Polski późnego średniowiecza (Fasciculi Historici Novi, t. 4), red. M. Koczerska, Warszawa 2001, s. 87-187.

Czwojdrak Bożena, Dwory królewskie w Polsce w XV wieku - stan badań i postulaty badawcze, w: Curia regis, curia reginalis. Dwory królewskie w średniowiecznej Europie Środkowej - stan badań i postulaty badawcze, red. B. Czwojdrak, A. Januszek-Sieradzka, Sandomierz 2014, s. 59-71.

Czwojdrak Bożena, Fraucymer na dworach królowych w późnośredniowiecznej Polsce, „Studia z dziejów średniowiecza”, 20 (2016) s. 17-28.

Czwojdrak Bożena, Liczebność dworów późnośredniowiecznych $i$ wczesnonowożytnych władców polskich, „Roczniki Dziejów Społecznych i Gospodarczych”, 76 (2016), s. 209-220.

Czwojdrak Bożena, Z badań nad dworem królowej Zofii Olszańskiej, „Średniowiecze Polski i Powszechne", 2 (6) (2010) s. 157-178.

Czwojdrak Bożena, Zofia Holszańska. Studium o dworze i roli królowej w późnośredniowiecznej Polsce, Warszawa 2012.

Friedberg Marian, Klientela świecka biskupa krakowskiego w wieku XII-XIV, Kraków 1938.

Grabowski Janusz, Dokumenty i kancelaria biskupa płockiego Klemensa Pierzchaty w latach (1333-1357), w: Państwo i Kościót w dziejach, źródlach i studiach nad przeszłościq, red. M. Stawski, Warszawa 2008, s.145-168.

Grzybowski Michał Marian, Zyner Leszek, Episkopat ptocki w latach 1075-2015. 940 lat istnienia diecezji, Płock 2015.

Hain Stefan, Wincenty Kot prymas Polski 1436-1448, Poznań 1948. 
Koczerska Maria, Zbigniew Oleśnicki i Kościół krakowski w czasach jego pontyfikatu 1423-1455, Warszawa 2004.

Kręt Helena, Dwór królewski Jadwigi i Jagietty, Kraków 1987.

Rutkowska Grażyna, Dwór królewski w Polsce w XIV wieku - stan badań i postulaty badawcze, w: Curia regis, curia reginalis. Dwory królewskie w średniowiecznej Europie Środkowej - stan badań i postulaty badawcze, red. B. Czwojdrak, A. Januszek-Sieradzka, Sandomierz 2014, s. 45-57.

Rutkowska Grażyna, Itineraria żon króla Władysława Jagietly, „Roczniki Historyczne”, 64 (1998), s. 59-104.

Rutkowska Grażyna, Urzędnicy królowej Jadwigi Andegaweńskiej. Spis, w: Nihil superfluum esse. Prace z dziejów średniowiecza ofiarowane Profesor Jadwidze Krzyżaniakowej, red. J. Strzelczyk, J. Dobosz, przy współpracy Z. Górczaka, Poznań 2000, s. 367-391.

Skierska Izabela, Dwór i urząd biskupi w późnośredniowiecznej diecezji poznańskiej, „Roczniki Historyczne”, 60 (1994) s. 185-202.

Sperka Jerzy, Otoczenie Władysława Opolczyka w latach 1370-1401. Studium o elicie władzy w relacjach z monarcha, Katowice 2006.

Suchodolska Ewa, Kancelarie na Mazowszu w latach 1248-1345.Ośrodki zarządzania i kultury, Warszawa 1977.

Supruniuk Anna, Otoczenie księcia mazowieckiego Siemowita IV (1374-1426). Studium o elicie politycznej Mazowsza na przełomie XIV i XV wieku, Warszawa 1998.

Tomczak Andrzej, Kancelaria biskupów włocławskich w okresie księgi wpisów (XV-XVIII w.), Toruń 1964.

Umiński Jan, Andrzej h. Ciołek, biskup płocki, w: Polski Słownik Biograficzny, t. 1, Kraków 1935, s. 102.

Wilk-Woś Zofia, Późnośredniowieczna kancelaria arcybiskupów gnieźnieńskich (14361493), Łódź 2013.

Wilk-Woś Zofia, Władysław z Oporowa (ok. 1395-1453). Podkanclerzy królewski, biskup włocławski i arcybiskup gnieźnieński, „Studia Claramontana”, 21 (2003) s. 175-459.

Włodarski Łukasz, Dwór i najbliższe otoczenie arcybiskupa gnieźnieńskiego Jarosława Bogorii ze Skotnik (1342-1374), „Studia z Dziejów Średniowiecza”, 19 (2015), s. $225-256$.

Żebrowski Tadeusz, Zarys dziejów diecezji płockiej, Płock 1976.

\section{URZĘDNICY DWORSCY BISKUPA PLOCKIEGO ANDRZEJA \\ HERBU CIOLEK (1254-1261). \\ PRZYCZYNEK DO BADAŃ NAD DWORAMI BISKUPIMI \\ W ŚREDNIOWIECZNEJ POLSCE}

\section{Streszczenie}

Niniejszy przyczynek stawia sobie za cel prezentację urzędników dworskich ordynariusza płockiego Andrzeja h. Ciołek, niemniej ze względu na szczupłość i lakoniczność przekazów źródeł jest to zadanie znacznie utrudnione. W świetle zachowanych materia- 
łów wiadomo, że jego otoczenie składało się z osób, które dbały o zaspokojenie jego potrzeb doczesnych, tj. przygotowanie posiłków oraz stołu do ich spożywania, komnaty do spania, zarządzanie dobrami lub reprezentowanie biskupa przez osobę prokuratora, a także kapelanów będącymi prawdopodobnie pracownikami kancelarii, która umożliwiała sprawne zarządzanie diecezją.

Słowa kluczowe: dwór; urzędnicy; biskup; Kościół; Płock; XIII wiek

\title{
THE COURT OFFICIALS OF THE BISHOP OF PLOCK, ANDRZEJ OF THE CIOLEK COAT OF ARMS (1254-1261). AN ARTICLE ABOUT RESEARCH ON BISHOP'S COURTS IN MEDIEVAL POLAND
}

\begin{abstract}
Summary
The following article aims to present court officials of the Ordinary Bishop of Płock, Andrzej Ciołek. However, due to a shortage of the sources and their laconic nature, this task is much more difficult. The surviving material reveals that the bishop's closest circle comprised the people who satisfied his earthly needs, namely preparing meals, tables, sleeping chambers as well as managing bishop's property. In addition, the bishop was represented by a prosecutor. There were also priests who probably worked in the church office, which enabled efficient management of the diocese.
\end{abstract}

Keywords: court; officials; a bishop; the Church; Płock; 13th century 